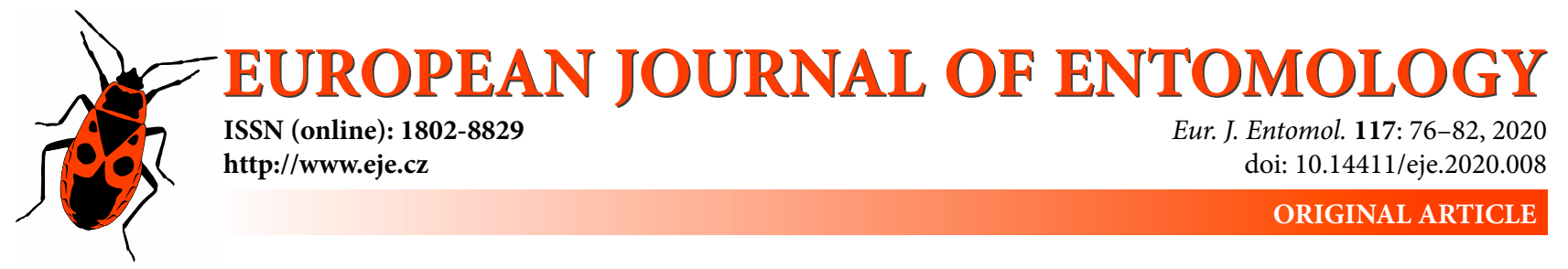

\title{
Barrier pitfall traps increase captures of ground beetles (Coleoptera: Carabidae) on exposed riverine sediments
}

\author{
SCOTT HORN \\ USDA Forest Service, Southern Forestry Sciences Laboratory, 320 Green Street, Athens, GA 30602, USA; \\ e-mail: scott.horn@usda.gov
}

Key words. Coleoptera, Carabidae, exposed riverine sediments, pitfall trap, sandbar, efficiency, psammophilous, riparian

\begin{abstract}
Exposed riverine sediments are unique riparian environments that exhibit high biodiversity and harbor many specialist species. Ground beetles are the most well studied inhabitants within these environments where they are often sampled using pitfall traps. In order to develop conservation measures for species occupying these habitats a logical first step is to refine sampling methods so that proper biodiversity assessments can be carried out. To that end, the effectiveness of two pitfall trap designs (standard trap vs. barrier trap) was evaluated. Over three sampling periods we collected 5,186 individuals represented by 43 species. Barrier traps proved to be superior, yielding significantly greater numbers of individuals ( $n=3,456$ vs. 1,730 ) than standard traps. Additionally, we collected more ground beetle species (37 vs. 30) in barrier traps than in standard pitfall traps. This study supports the rationale for deployment of more than one trap design to avoid deficiencies exhibited by a single type.
\end{abstract}

\section{INTRODUCTION}

Exposed riverine sediments (ERS) are sparsely vegetated areas consisting of gravel, sand, or silt that occur between the stream bank and the water's edge. This ecotone generally has a high level of habitat heterogeneity associated with high beetle diversity (Bates et al., 2007a). The lack of vegetation, extreme temperatures, and frequent inundation lead to a dynamic system replete with rare species of arthropods (Bates et al., 2009 and sources therein), many of which are specialists adapted to the physical or climatic extremes within this unique environment (Eyre et al., 2001; Sadler et al., 2004; Lambeets et al., 2009). As a result of this specialization, many of these invertebrates are vulnerable to anthropogenic alterations of rivers and streams and thus serve as model organisms to study impacts of human-induced change (O'Callaghan et al., 2013; Langhans \& Tockner, 2014; Sinnadura et al., 2016).

Many of the beetles residing on ERS exploit aquatic food sources (Hering \& Plachter, 1997; Paetzold et al., 2005) whereas others predominantly known to occur in forested habitats have been caught on ERS suggesting that they are opportunistically taking advantage of resources stranded near the water's edge (Horn \& Ulyshen, 2009). Due to the importance of these unique environments to the surrounding riparian system, as well as the sensitivity and vulnerability of these habitats, appeals have been directed at the restoration and conservation of ERS in North America (U1yshen \& Horn, 2010) and Europe (Bates et al., 2009). This research has focused on the ecological consequences of major threats like channelization, damage from livestock, gravel and sand extraction, and dams (Knisley \& Fenster, 2005; Sadler et al., 2006; Bates et al., 2007b; Paetzold et al., 2008). In order to maximize monitoring programs aimed at pinpointing causal agents of ERS degradation and subsequent acts of restoration, it is imperative to develop sampling methods that are both easy to deploy and highly effective for targeted organisms.

Many invertebrate groups reside on ERS but none are as prominent and well-studied as ground beetles (Carabidae). Carabids are often considered a model taxon when it comes to evaluating human impacts to natural ecosystems (i.e. "bioindicator") because they (1) are easy to identify and collect, (2) have wide distributions, (3) are present in large numbers, (4) are often specialized in their habitat preferences, and (5) can reflect changes to defined habitats (Rainio \& Niemelä, 2003; Pearce \& Venier, 2006; Koivula, 2011; Cajaiba et al., 2018). Studies have successfully monitored ground beetle species and/or communities to assess the effects of various forest management prescriptions such as fire (Beaudry et al., 1997; Hanula \& Wade, 2003), clearcutting (Duchesne et al., 1999; Pearce et al., 2003) and gap harvesting (Klimaszewski et al., 2005; Ulyshen et al., 2005a) demonstrating their usefulness at detecting change. Likewise, they have proven effective as potential indicators to environmental pollution through bioaccumulation (Conti, 2017). Regardless of the habitat or disturbance type sampled, a large majority of carabid studies use pitfall traps. 

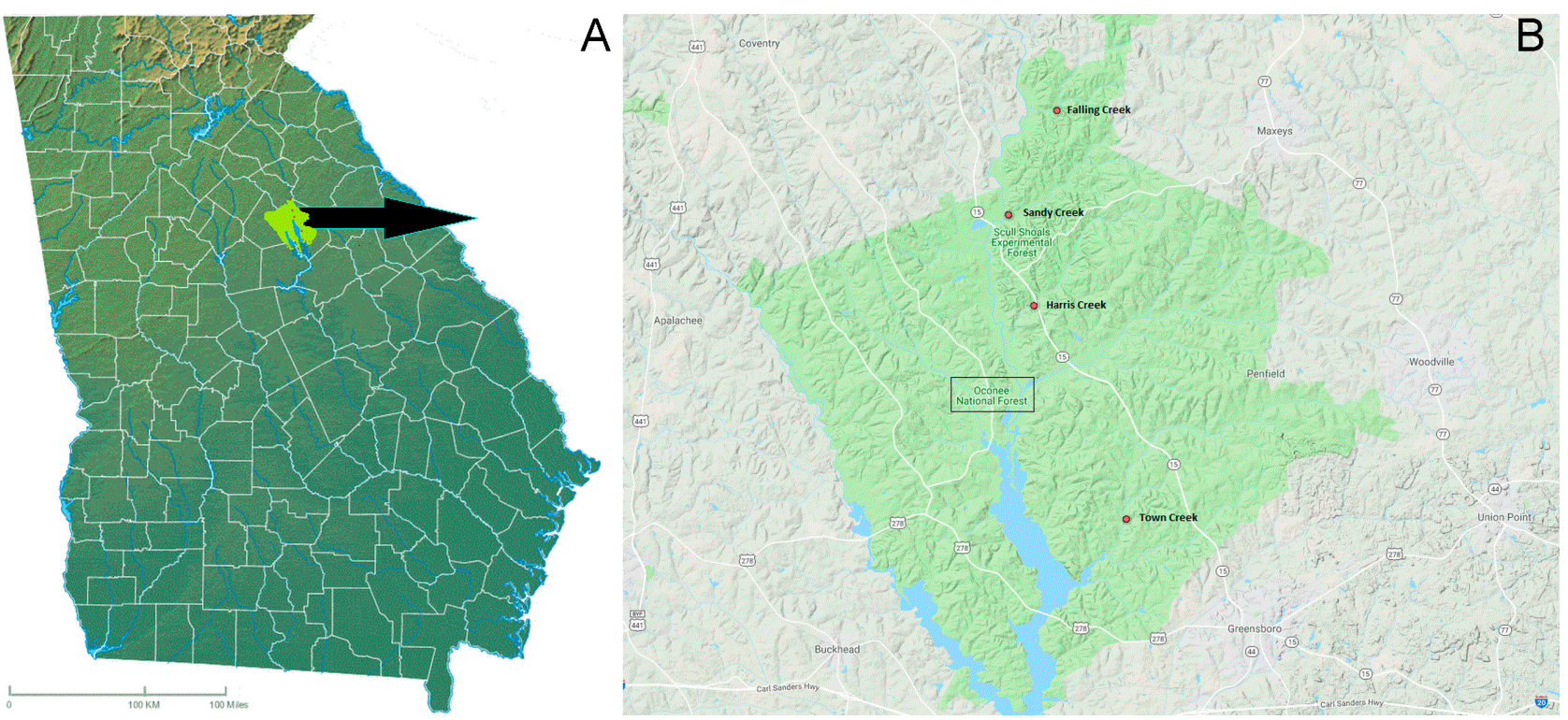

Fig. 1. (A) Map showing regional location of study within the state of Georgia, USA and (B) individual stream locations within the National Forest and Oconee River watershed.

Although many methods are routinely used to sample ground-dwelling arthropods, pitfall traps remain the most utilized and effective method for measuring ground beetle populations for ecological studies, although some limitations do exist. For example, they tend to be biased towards larger species (Spence \& Niemelä, 1994; Hancock \& Legg, 2012) and have the potential to reduce local populations (Digweed et al., 1995; Slezák et al., 2010). Moreover, it has been pointed out that pitfalls reflect 'activity density' of terrestrial arthropods rather than true abundance (Lövei \& Sunderland, 1996; Kotze et al., 2011; Brown \& Matthews, 2016), therefore data interpretation should be treated accordingly, but still no other method is as cost-effective, easy to deploy, and repeatable under various environmental conditions.

Despite widespread use of pitfall traps there have been calls for a standard design (Hancock \& Legg, 2012; Brown \& Matthews, 2016) so that studies from around the world can be reported and interpreted in a comparable fashion. This can be partly attributed to the vast amount of work that has been conducted on variations in trap design, ranging from the influence of color (Buchholz et al., 2010), preservatives (Knapp \& Růžička, 2012; Skvarla et al., 2014), presence of covers (Buchholz \& Hannig, 2009; Csaszar et al., 2018), use of funnels (Radawiec \& Aleksandrowicz, 2013; Csazar et al., 2018), diameter of the opening size (Koivula et al., 2003; Lange et al., 2011), and barriers (Durkis \& Reeves, 1982; Mommertz et al., 1996; Holland \& Smith, 1999; Winder et al., 2001; Brennan et al., 2005; Hansen \& New, 2005; Boetzl et al., 2018).

Determining efficiency of different pitfall trap designs under various environmental conditions seems to be a simple, yet plausible undertaking. Much effort has been directed at comparing the various designs. However, consideration should also be directed on how each of these designs perform in different habitats, because vegetative structure and microclimate may differentially affect trap catch according to pitfall trap design (Phillips \& Cobb, 2005; Taboada et al., 2006; Thomas et al., 2006). To date, most studies conducted using pitfall traps on ERS have used a single cup method without a barrier (Eyre et al., 2001; Eyre \& Luff, 2002; Sadler et al., 2004; Bates et al., 2005, 2007a; Horn \& Ulyshen, 2009). The objective of this study was to sample ERS ground beetle communities along four streams and determine if pitfall trap design made a difference in assessing their populations in those areas.

\section{MATERIALS AND METHODS}

\section{Site description}

This study was conducted along four secondary streams (Town Creek: $33^{\circ} 36^{\prime} 49.0608^{\prime \prime} \mathrm{N}, 8^{\circ} 14^{\prime} 19.5072^{\prime \prime} \mathrm{W}$, Harris Creek: $33^{\circ} 42^{\prime} 28.9764^{\prime \prime} \mathrm{N}, 83^{\circ} 17^{\prime} 30.1236^{\prime \prime} \mathrm{W}$, Falling Creek: $33^{\circ} 47^{\prime} 3.6852^{\prime \prime} \mathrm{N}, 83^{\circ} 14^{\prime} 31.3116^{\prime \prime} \mathrm{W}$, and Sandy Creek: $33^{\circ} 43^{\prime}$ $28.6572^{\prime \prime} \mathrm{N}, 83^{\circ} 17^{\prime} 20.976^{\prime \prime} \mathrm{W}$; Google Maps, 2018) (Fig. 1) within the Oconee National Forest in Oglethorpe and Greene County, GA, USA. All streams were within the Oconee River Basin which is located within the Piedmont Physiographic Region, an area that was reforested starting in the 1940's after extensive degradation due to cotton farming. The lasting impacts to these waterways from the devastating erosion that occurred are large volumes of sediment within the streams bordered by steep banks and gullies (Edwards et al., 2013). Current forests are now dominated by over-story species such as willow oak (Quercus phellos L.), water oak (Quercus nigra L.), sycamore (Platanus occidentalis L.), sweetgum (Liquidambar styraciflua L.), black walnut (Juglans nigra L.), and loblolly pine (Pinus taeda L.). Common mid/understory species include spicebush (Lindera benzoin (L.) Blume), Georgia buckeye (Aesculus sylvatica W. Bartram), Carolina silverbell (Halesia carolina L.), ironwood (Carpinus caroliniana Walter), and Chinese privet (Ligustrum sinense Lour.).

The four streams were all located within $17 \mathrm{~km}$ of one another and very similar in nature (i.e. flow rates, sediment loads, sediment size, surrounding canopy cover, etc.). Individual sandbars (Fig. 2) were composed of fine sand with low amounts of deposited leaf litter and some coarse woody debris. Sandbars averaged about $20 \mathrm{~m}$ in length and $5 \mathrm{~m}$ in width. In spring and early 


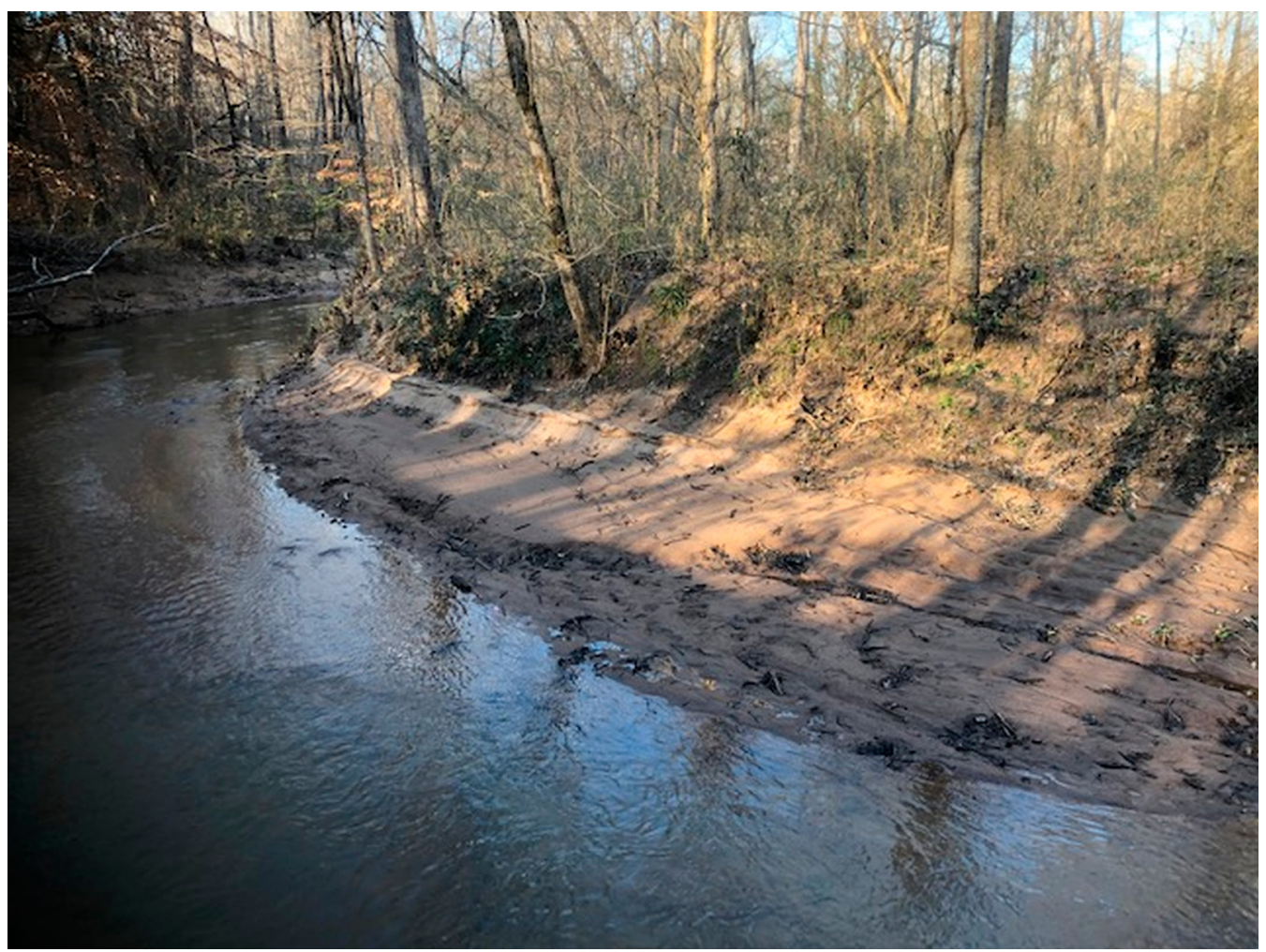

Fig. 2. Typical view of sand-dominated exposed riverine sediments which occur along secondary streams in the study area.

summer sandbars had little to no vegetation occurring on them, however by late summer to fall there was a limited amount of herbaceous plant growth.

\section{Beetle trapping}

For each of the four streams we selected four sandbars upon which to place a pair of traps for comparison. Traps were placed approximately $8-10 \mathrm{~m}$ apart depending on sandbar size, as well as spaced halfway between the bank and water's edge. At each stream the four sandbar samples were collected and combined by "trap type" ( 8 total samples each collection period). The standard trap consists of a $480 \mathrm{ml}$ plastic cup fitted with an $8.4 \mathrm{~cm}$ diameter funnel designed to direct beetles into a $120 \mathrm{ml}$ specimen cup (i.e. Horn \& Ulyshen, 2009) (Fig. 3A). Second, the same cup dimensions were used as described above except that each was positioned at the intersection of four $0.5 \mathrm{~m}$ long metal barriers (forming an "X") (i.e. Ulyshen et al., 2005a, b) (Fig. 3B). The preservative used in the collection cups was a $2 \%$ formaldehyde and saturated $\mathrm{NaCl}$ solution with a few drops of dish detergent added to reduce surface tension.

Upon collection, samples were transferred to $70 \%$ ethanol for storage until they could be identified using a local reference collection (USDA Forest Service, Forestry Sciences Laboratory Collection) and regional ground beetle key (Ciegler, 2000). While not in operation, a square ceramic tile $(10.5 \mathrm{~cm} \times 10.5 \mathrm{~cm})$ was placed over all cup openings to prevent the accidental capture of other organisms. Pitfall traps were operated for three 5-day intervals in 2008 and the collection dates were as follows: 25 April, 30 May, and 11 July. The reported annual rainfall amount for the area in 2008 was $92.38 \mathrm{~cm}$ which is lower than average and the amounts for the trapping periods were: $7.62 \mathrm{~cm}$ (April), $5.66 \mathrm{~cm}$ (May), and $10.03 \mathrm{~cm}$ (July). Mean temperatures for the trapping periods were $16.2^{\circ} \mathrm{C}$ for April, $20.6^{\circ} \mathrm{C}$ for May, and $26.8^{\circ} \mathrm{C}$ for July.
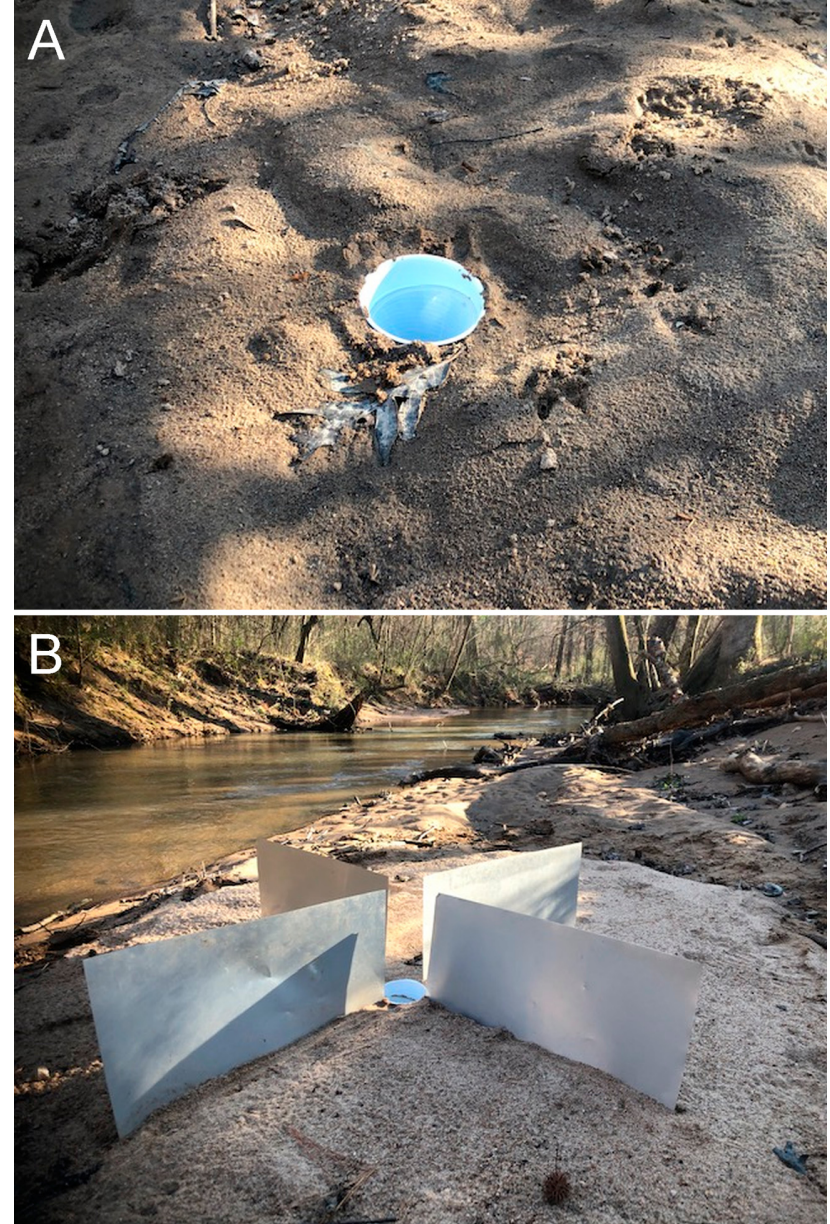

Fig. 3. (A) Standard pitfall trap and (B) Barrier pitfall trap used for collection of ground beetles on exposed riverine sediments in this study. 


\section{Statistical analyses}

Individual sandbar collections (4 sandbars) were combined at each stream location ( 4 streams) by trap type ( 2 trap designs) for a total of 8 samples each trapping period. The data was normally distributed according to a Shapiro-Wilk normality test, $(\mathrm{P}$ $=0.282$ ). To avoid a lack of independence, the sampling periods were pooled and a paired t-test (SYSTAT 8.0) was used to determine if trap design resulted in differences of mean abundance for ground beetles active on ERS in our area. In addition, a oneway PERMANOVA using PC-ORD (McCune \& Mefford, 2011) was performed to determine if community composition differed between the two trap designs. Different sampling periods were pooled for this analysis and only the 19 species captured in at least 3 of the 8 samples each month were included. The same

Table 1. Total number of ground beetle specimens for each species captured on sandbars from two pitfall trap designs. Numbers reflect total abundance for the four streams sampled and across all sampling periods combined.

\begin{tabular}{|c|c|c|}
\hline \multirow[b]{2}{*}{ Ground beetle taxon } & \multicolumn{2}{|c|}{ Total number } \\
\hline & $\begin{array}{l}\text { Standard } \\
\text { pitfall }\end{array}$ & $\begin{array}{c}\text { Barrier } \\
\text { pitfall }\end{array}$ \\
\hline Agonum extensicolle (Say, 1823) & 127 & 337 \\
\hline Agonum ferreum Haldeman, 1843 & 23 & 41 \\
\hline Agonum spp. Bonelli, 1810 & 0 & 1 \\
\hline Amara spp. Bonelli, 1810 & 2 & 5 \\
\hline Anisodactylus melanopus (Haldeman, 1843) & 0 & 1 \\
\hline Anisodactylus verticalis (LeConte, 1848) & 3 & 0 \\
\hline Badister flavipes LeConte, 1853 & 0 & 1 \\
\hline Badister notatus Haldeman, 1843 & 0 & 2 \\
\hline Bembidion aenulum Hayward, 1901 & 86 & 316 \\
\hline Bembidion inaequale Say, 1823 & 30 & 26 \\
\hline Bembidion versicolor (LeConte, 1848) & 6 & 3 \\
\hline Brachinus alternans Dejean, 1825 & 17 & 10 \\
\hline Brachinus americanus (LeConte, 1844) & 3 & 0 \\
\hline Brachinus janthinipennis (Dejean, 1831) & 537 & 1015 \\
\hline Carabus vinctus (Weber, 1801) & 0 & 1 \\
\hline Chlaenius aestivus Say, 1823 & 69 & 191 \\
\hline Chlaenius impunctifrons Say, 1823 & 0 & 1 \\
\hline Chlaenius nemoralis Say, 1823 & 1 & 1 \\
\hline Chlaenius prasinus Dejean, 1826 & 1 & 1 \\
\hline Cicindela repanda Dejean, 1825 & 62 & 51 \\
\hline Cicindela sexguttata Fabricius, 1775 & 30 & 23 \\
\hline Clivina bipustulata (Fabricius, 1801) & 3 & 4 \\
\hline Clivina dentipes Dejean, 1825 & 3 & 8 \\
\hline Clivina ferrea LeConte, 1857 & 2 & 0 \\
\hline Dicaelus dilatatus Say, 1823 & 0 & 1 \\
\hline Dicaelus elongates Bonelli, 1813 & 2 & 3 \\
\hline Dyschirius spp. Bonelli, 1810 & 1 & 1 \\
\hline Elaphrus ruscarius Say, 1830 & 0 & 5 \\
\hline Galerita bicolor (Drury, 1773) & 1 & 0 \\
\hline Harpalus pennsylvanicus (DeGeer, 1774) & 0 & 1 \\
\hline Loxandrus spp. LeConte, 1852 & 0 & 1 \\
\hline Omophron americanum Dejean, 1831 & 546 & 1041 \\
\hline Oodes brevis Lindroth, 1957 & 2 & 8 \\
\hline Panagaeus fasciatus Say, 1823 & 0 & 1 \\
\hline Paratachys spp. Casey, 1918 & 2 & 33 \\
\hline Patrobus longicornus (Say, 1823) & 2 & 6 \\
\hline Platynus dicentis (Say, 1823) & 0 & 1 \\
\hline Poecilus lucublandus (Say, 1823) & 1 & 0 \\
\hline Scarites quadriceps Chaudoir, 1843 & 1 & 0 \\
\hline Scarites subterraneus Fabricius, 1775 & 1 & 1 \\
\hline Schizogenius ferrugineus Putzeys, 1846 & 121 & 253 \\
\hline Semiardistomis viridis (Say, 1823) & 45 & 60 \\
\hline Stenolophus ochropezus (Say, 1823) & 0 & 1 \\
\hline
\end{tabular}

*All nomenclature follows that used by Larochelle \& Larivière (2003) and Ciegler (2000).

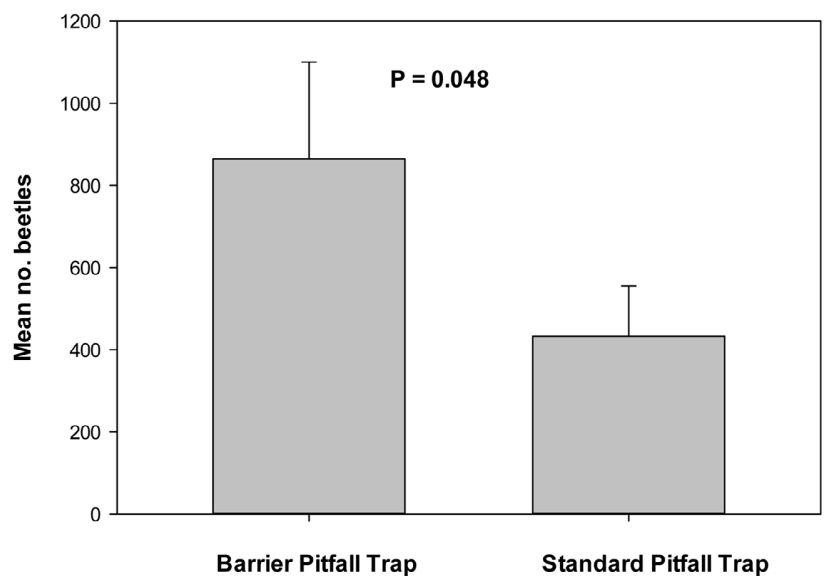

Fig. 4. Mean number $(\bar{x}+S E)$ of ground beetles captured in each pitfall trap design. Significance based on a paired t-test after sampling periods were pooled $(P<0.05)$.

dataset was used to perform an indicator species analysis using PC-ORD following the approach of Dufrene \& Legendre (1997) to determine if certain species seemed to be associated with trap type.

\section{RESULTS AND DISCUSSION}

This study yielded a total of 5,186 specimens between the two trap designs, represented by 43 species (Table 1). The barrier traps caught almost twice as many individual ground beetles as the standard traps ( $\mathrm{n}=3,456$ vs. 1,730 ) where they accounted for $66 \%$ of the total. A paired $t-$ test revealed significant differences in the mean number of ground beetles collected from barrier pitfall traps (M $=864, \mathrm{SD}=473.33)$ and standard traps $(\mathrm{M}=432.5, \mathrm{SD}$ $=245.49) ; \mathrm{t}(3)=3.23, \mathrm{P}=0.048$. (Fig. 4). There is evidence in other habitats that support the finding that barriers increase arthropod catch. For example, Durkis \& Reeves (1982) sampled a mixed hardwood forest in New Hampshire and found that not only did a barrier increase their catch of ground beetles, but captures went up with length of the fence design as well. Similarly, Hansen \& New (2005) found that the use of a trap barrier consistently caught more individuals and morphospecies than a conventional trap in an open, grassy woodland of Australia. Moreover, a study conducted in Germany in a semi-natural meadow revealed that pitfall traps with barriers were up to five times more effective than conventional traps and were more reflective in their species assemblage approximations (Boetzl et al., 2018). These studies, as well as the results reported here from ERS show that barrier pitfall traps are useful for increasing ground beetle catches no matter the habitat sampled.

Although barriers increased the numbers of ground beetles captured, an indicator species analysis revealed no species were indicative of trap type. Likewise, a PERMANOVA showed that the community composition did not differ significantly between the trap designs $(F=0.60$; df $=1,6$; $P=0.6846$ ). In contrast, Boetzl et al. (2018) caught twice as many species in barrier traps and their species accumulation curves indicate that one of these traps is equal to 
deployment of four or five simple pitfall traps. They conclude that conventional traps might be necessary for comparisons with existing literature, but barrier traps are far superior for studies concerned with biodiversity inventories. Information from the present study seems to support this conclusion because thirteen of the recorded species were captured only in barrier traps while 6 were found only in standard pitfalls, often represented by a single specimen. This underscores the importance of deploying multiple trap types, especially when trying to assess the presence of as many taxa as possible. For example, Mommertz et al. (1996) evaluated trap construction within an agroecosystem and concluded that unfenced traps overestimate the percentage of ground beetles present and that the use of multiple designs are advisable to overcome shortcomings exhibited by just one type of trap.

Table 1 includes all carabid species encountered during sampling as well as the number caught by each trap design. The most commonly collected species were Omophron americanum, Brachinus janthinipennis, Agonum extensicolle, Bembidion aenulum, Schizogenius ferrugineus, Chlaenius aestivus, and Cicindela repanda. Each of these species were captured in higher numbers from barrier pitfall traps with the exception of the bronzed tiger beetle, $C$. repanda. The only other tiger beetle captured, $C$. sexguttata was also caught more often in standard traps without a barrier. Most tiger beetles are diurnal and exhibit a stop and look hunting style (Pearson et al., 2006). This behavior likely reduces the chance of them being "directed" into a trap by a barrier fence. Physical characteristics such as body size have also been proposed as a possible factor influencing capture rates. Winder et al. (2001) found some evidence that smaller species of ground beetles might be more prone to collection with traps using barrier fences but the results were inconsistent. Findings here were similar when ground beetles were classified as either being small ( $<10 \mathrm{~mm}$ body length) or large ( $>10 \mathrm{~mm}$ body length). Barrier traps accounted for $67 \%$ of small-bodied and $61 \%$ of large-bodied ground beetles collected suggesting that smaller beetles might be more susceptible to capture if directed by a fence.

As is often the case when invertebrates are sampled, distributions are highly skewed, with many rare species present and only a few common ones that make up the bulk of the community (Verberk, 2011). That was the case in this study as well where 24 of the 43 species were represented by five or less individuals. The ground beetle captured most frequently was the hunch-backed beetle, $O$. americanum which accounted for $31 \%$ of the total catch while $B$. janthinipennis made up 30\%. These two beetles accounted for the majority of captures in a previous study conducted on one of the four streams utilized here (Horn \& Ulyshen, 2009), thus it was not a surprise that they were common on nearby streams with similar characteristics. $O$. americanum is a burrowing, mostly nocturnal species that is restricted to the vicinity of water on sparsely vegetated sandy substrates (Lindroth, 1961; Larochelle \& Larivière, 2003). Lakeshores, riverbanks, and moist sandy soils are listed as typical habitat for $B$. janthinipennis where it is reported to be an ectoparasite of gyrinid (Dineutes spp.) and hydrophilid (Tropisternus spp.) pupae (Larochelle \& Larivière, 2003).

Carabid seasonality can be influenced by many factors such as their abundance, breeding or dormancy periods, and larval development but many of the species that occur in disturbed habitats (i.e. dynamic stream systems) can exhibit various levels of plasticity (Rainio, 2013). Results presented here are consistent with earlier work in the same habitats (Horn \& Ulyshen, 2009) and reveal that the earliest trapping session in April yielded the most abundance and diversity ( $\mathrm{n}=3,010$ and 35 species) from which it declined the following two sampling periods in May $(\mathrm{n}=$ 1,545 and 29 species) and July ( $=631$ and 15 species). This is in line with seasonality records for the most commonly collected species, as well as breeding records for $O$. americanum that have reported it to be a spring breeder (Larochelle \& Larivière, 2003).

There are several reasons why this community might be tilted towards larger populations early in the season. First, it could be a result of beetle communities within this dynamic system being strongly tied to early season resource availability that occur from late winter/early spring flooding. Evidence exists that some taxa, e.g. tiger beetles are strongly influenced by the availability of food (Pearson \& Knisley, 1985), thus it stands to reason that their seasonality would be closely linked to times when it is most readily available. Secondly, traps could have shown reduced catches because beetle activity was restricted due to increases in vegetation density (i.e. Honěk, 1988; Thomas et al., 2006) on the sandbars as the season progressed. Lastly, a "trap-out" effect could explain part of the declines given that the two most commonly collected species seem to be restricted to these relatively small sandbars adjacent to the water's edge thus rendering populations vulnerable to reduction over time.

Recent studies (Hallmann et al., 2017; Sánchez-Bayo \& Wyckhuys, 2019) have sounded the alarm on global insect declines and ushered in a discussion about the negative effects to the planet due to the loss of ecosystem services they provide. In order to develop conservation strategies for insects as a whole, it is vital to identify which groups are most at risk and then employ efficient monitoring protocols to determine if management actions are needed. My objective in this study was to determine if trap design would make a difference on the diversity and abundance of ground beetle catches on exposed riverine sediments, especially given how prominent this unique habitat is on secondary streams in our area. This study showed that the community did not differ between traps on the four streams sampled, however it does indicate that barrier traps are more effective based on the collection of greater numbers of individuals and species from that design. This study aligns with previous work that has recommended incorporating multiple trap types into studies to alleviate the biases associated with a particular style. In addition, because exposed riverine sediments serve as habitat to many stenotopic species, barrier 
traps might be the best option for biodiversity assessments. Future studies are needed to determine how these traps perform in different regions, over longer periods of time, and under different environmental conditions.

ACKNOWLEDGEMENTS. Special thanks to M.D. Ulyshen for help with statistical analyses and H. Lee Jr. for determination of many ground beetle species.

\section{REFERENCES}

Bates A.J., SAdler J.P., Fowles A.P. \& Butcher C.R. 2005: Spatial dynamics of beetles living on exposed riverine sediments in the Upper River Severn: method development and preliminary results. - Aquat. Conserv. 15: 159-174.

Bates A.J., Sadler J.P., Perry J.N. \& Fowles A.P. 2007a: The microspatial distribution of beetles (Coleoptera) on exposed riverine sediments (ERS). — Eur. J. Entomol. 104: 479-487.

Bates A.J., Sadler J.P. \& Fowles A.P. 2007b: Livestock trampling reduces the conservation value of beetle communities on high quality exposed riverine sediments. - Biodiv. Conserv. 16: 1491-1509.

Bates A.J., Sadler J.P., Henshall S.E. \& Hannah D.M. 2009: Ecology and conservation of arthropods of exposed riverine sediments (ERS). - Terr. Arthropod Rev. 2: 1-22.

Beaudry S., Duchesne L.C. \& CôTé B. 1997: Short-term effects of three forestry practices on carabid assemblages in a jack pine forest. - Can. J. For. Res. 27: 2065-2071.

Boetzl F.A., Ries E., Schneider G. \& Krauss J. 2018: It's a matter of design - how pitfall trap design affects trap samples and possible predictions. - PeerJ 6: e5078, 14 pp.

Brennan K.E.C., MoIR M.L. \& MaJer J.D. 2005: Refining sampling protocols for inventorying spider biodiversity: influence of drift-fence length and pitfall trap diameter. - J. Arachnol. 33: 681-702.

Brown G.R. \& Matthews I.M. 2016: A review of extensive variation in the design of pitfall traps and a proposal for a standard pitfall trap design for monitoring ground-active arthropod biodiversity. - Ecol. Evol. 6: 3953-3964.

Buchiolz S. \& Hannig K. 2009: Do covers influence the capture efficiency of pitfall traps? - Eur. J. Entomol. 106: 667-671.

Buchiolz S., Jess A.M., Hertenstein F. \& Schirmel J. 2010: Effect of the colour of pitfall traps on their capture efficiency of carabid beetles (Coleoptera: Carabidae), spiders (Araneae) and other arthropods. - Eur. J. Entomol. 107: 277-280.

Cajaiba R.L., Périco E., Silva W.B., Vieira T.B., Dalzochio M.S., Bastos R., Cabral J.A. \& Santos M. 2018: How informative is the response of Ground Beetles' (Coleoptera: Carabidae) assemblages to anthropogenic land use changes? Insights for ecological status assessments from a case study in the Neotropics. - Sci. Total Environ. 636: 1219-1227.

CIEGLER J.C. 2000: Ground Beetles and Wrinkled Bark Beetles of South Carolina (Coleoptera: Geadephaga: Carabidae and Rhysodidae). Biota of South Carolina, Vol. 1. Clemson University. Clemson, SC, 149 pp.

ConTI E. 2017: Ecotoxicological evaluation of Parallelomorphus laevigatus (Coleoptera, Carabidae) as a useful bioindicator of soil metal pollution. - Adv. Tech. Biol. Med. 5: 1-3.

Császár P., Torma A., Gallé-Szpisjak N., Tölgyesi C. \& Gallé R. 2018: Efficiency of pitfall traps with funnels and/or roofs in capturing ground-dwelling arthropods. - Eur. J. Entomol. 115: $15-24$.

Digweed S.C., Currie C.R., Carcamo H.A. \& Spence J.R. 1995: Digging out the 'digging-in effect' of pitfall traps: influences of depletion and disturbance on catches of ground beetles (Coleoptera: Carabidae). — Pedobiologia 39: 561-576.

Duchesne L.C., Lautenschlager R.A. \& Bell F.W. 1999: Effects of clear-cutting and plant competition control methods on carabid (Coleoptera: Carabidae) assemblages in northwestern Ontario. - Environ. Monit. Assess. 56: 87-96.

Dufrene M. \& Legendre P. 1997: Species assemblages and indicator species: The need for a flexible asymmetrical approach. -Ecol. Monog. 67: 345-366.

DuRkis T.J. \& ReEves R.M. 1982: Barriers increase efficiency of pitfall traps. - Entomol. News 93: 8-12.

Edwards L., Ambrose J. \& Kirkman L. 2013: The Natural Communities of Georgia. University of Georgia Press, Athens, 675 pp.

EyRE M.D. \& LufF M.L. 2002: The use of ground beetles (Coleoptera: Carabidae) in conservation assessments of exposed riverine sediment habitats in Scotland and northern England. - J. Insect Conserv. 6: 25-38.

Eyre M.D., Luff M.L. \& Phillips D.A. 2001: The ground beetles (Coleoptera: Carabidae) of exposed riverine sediments in Scotland and northern England. - Biodiv. Conserv. 10: 403-426.

Hallmann C.A., Sorg M., Jongejans E., Siepel H., Hofland N., Schwan H., Stenmans W., Múller A., Sumser H., Hörren T., Goulson D. \& DE Kroon H. 2017: More than 75 percent decline over 27 years in total flying insect biomass in protected areas. - PLoS ONE 12(10): e0185809, 21 pp.

Hancock M.H. \& LegG C.J. 2012: Pitfall trapping bias and arthropod body mass. - Insect Conserv. Divers. 5: 312-318.

HANSEN J.E. \& NEW T.R. 2005: Use of barrier pitfall traps to enhance inventory surveys of epigaeic Coleoptera. $-J$. Insect Conserv. 9: 131-136.

HANULA J.L. \& WADE D.D. 2003: Influence of long-term dormantseason burning and fire exclusion on ground-dwelling arthropod populations in longleaf pine flatwoods ecosystems. - For. Ecol. Manag. 175: 163-184.

Hering D. \& Plachter H. 1997: Riparian ground beetles (Coleoptera, Carabidae) preying on aquatic invertebrates: a feeding strategy in alpine floodplains. - Oecologia 111: 261-270.

Holland J.M. \& SMITH S. 1999: Sampling epigeal arthropods: an evaluation of fenced pitfall traps using mark-release-recapture and comparisons to unfenced pitfall traps in arable crops. Entomol. Exp. Appl. 91: 347-357.

HoNĚK A. 1988: The effect of crop density and microclimate on pitfall trap catches of Carabidae, Staphylinidae (Coleoptera), and Lycosidae (Araneae) in cereal fields. - Pedobiologia 32: 233-242.

Horn S. \& Ulyshen M.D. 2009: The importance of streamside sand bars to ground beetle (Coleoptera, Carabidae) communities in a deciduous forest. - J. Insect Conserv. 13: 119-123.

Klimaszewski J., Langor D.W., Work T.T., Pelletier G., HamMOND H.E.J. \& Germaine C. 2005: The effects of patch harvesting and site preparation on ground beetles (Coleoptera: Carabidae) in yellow birch dominated forests of southeastern Quebec. - Can. J. For. Res. 35: 2616-2628.

KNAPP M. \& RŮŽIČKA J. 2012: The effect of pitfall trap construction and preservative on catch size, species richness and species composition of ground beetles (Coleoptera: Carabidae). - Eur. J. Entomol. 109: 419-426.

Knisley C.B. \& Fenster M.S. 2005: Apparent extinction of the tiger beetle Cicindela hirticollis abrupta (Coleoptera: Carabidae: Cicindelinae). - Coleopt. Bull. 59: 451-458.

KorvULA M.J. 2011: Useful model organisms, indicators, or both? Ground beetles (Coleoptera, Carabidae) reflecting environmental conditions. - ZooKeys 100: 287-317. 
Koivula M., Kotze D.J., Hissivuori L. \& Rita H. 2003: Pitfall trap efficiency: do trap size, collecting fluid and vegetation structure matter? - Entomol. Fenn. 14: 1-14.

Kotze D.J., Brandmayr P., Casale A., Dauffy-Richard E., Dekoninck W., Koivula M., Lövei G.L., Mossakowski D., Noordijk J., Paarmann W., Pizzolotto R., Saska P., Schwerk A., Serrano J., Szysko J., Taboada A., Turin H., Venn S., Vermeulen R. \& Zetto T. 2011: Forty years of carabid beetle research in Europe - from taxonomy, biology, ecology and population studies to bioindication, habitat assessment and conservation. - ZooKeys 100: 55-148.

Lambeets K., Vandegehuchte M.L., Maelfait J.-P. \& Bonte D. 2009: Integrating environmental conditions and functional lifehistory traits for riparian arthropod conservation planning. Biodiv. Conserv. 142: 625-637.

LANGe M., Gossner M.M. \& Weisser W.W. 2011: Effect of pitfall trap type and diameter on vertebrate by-catches and ground beetle (Coleoptera: Carabidae) and spider (Araneae) sampling. - Methods Ecol. Evol. 2: 185-190.

LANGHANS S.D. \& TOCKNER K. 2014: Is the unsaturated sediment a neglected habitat for riparian arthropods? Evidence from a large gravel-bed river. - Global Ecol. Conserv. 2: 129-137.

Larochelle A. \& Larivière M.C. 2003: A Natural History of the Ground-Beetles (Coleoptera: Carabidae) of America North of Mexico. Pensoft, Sofia, 583 pp.

Lindroth C.H. 1961: The ground beetles (Carabidae, exc. Cicindelinae) of Canada and Alaska. Part 2. - Opusc. Entomol. (Suppl.) 20: 1-200.

Lövei G.L. \& SunderLAND K.D. 1996: Ecology and behavior of ground beetles (Coleoptera: Carabidae). - Annu. Rev. Entomol. 41: 231-256.

McCune B. \& MefFord M.J. 2011: PC-ORD. Multivariate Analysis of Ecological Data. Ver. 6. MjM Software, Gleneden Beach, Oregon.

Mommertz S., Schauer C., Kösters N., Lang A. \& Filser J. 1996: A comparison of D-Vac suction, fenced and unfenced pitfall trap sampling of epigeal arthropods in agro-ecosystems. - Ann. Zool. Fenn. 33: 117-124.

O'Callaghan M.J., Hannah D.M., Boomer I., Williams M. \& SADLER J.P. 2013: Responses to river inundation pressures control prey selection of riparian beetles. - PLOS ONE 8(4): e61866, $15 \mathrm{pp}$.

Paetzold A., Schubert C.J. \& Tockner K. 2005: Aquatic terrestrial linkages along a braided-river: riparian arthropods feeding on aquatic insects. - Ecosystems 8: 748-759.

Paetzold A., Yoshimura C. \& Tockner K. 2008: Riparian arthropod responses to flow regulation and river channelization. $-J$. Appl. Ecol. 45: 894-903.

Pearce J.L. \& Venier L.A. 2006: The use of ground beetles (Coleoptera: Carabidae) and spiders (Araneae) as bioindicators of sustainable forest management: a review. - Ecol. Indic. 6: 780-793.

Pearce J.L., Venier L.A., McKee J., Pedlar J. \& McKenney D. 2003: Influence of habitat and microhabitat on carabid (Coleoptera: Carabidae) assemblages in four stand types. - Can. Entomol. 135: 337-357.

Pearson D.L. \& Knisley C.B. 1985: Evidence for food as a limiting resource in the life cycle of tiger beetles (Coleoptera: Cicindelidae). - Oikos 45: 161-168.

Pearson D.L., Knisley C.B. \& Kasilek C.J. 2006: A Field Guide to the Tiger Beetles of the United States and Canada: Identification, Natural History, and Distribution of the Cicindelidae. Oxford University Press, New York, 227 pp.
Phillips I.D. \& Cовв T.P. 2005: Effects of habitat structure and lid transparency on pitfall catches. - Environ. Entomol. 34: 875-882.

RadAwiec B. \& AleKsandrowicz O. 2013: A modified pitfall trap for capturing ground beetles (Coleoptera: Carabidae). - Coleopt. Bull. 67: 473-480.

RAINIO J. 2013: Seasonal variation of ground beetle (Coleoptera: Carabidae) abundance and diversity in Ranomafana National Park, Madagascar. - J. Entomol. Zool. Stud. 1: 92-98.

RaINIO J. \& NIEMELÄ J. 2003: Ground beetles (Coleoptera: Carabidae) as bioindicators. - Biodiv. Conserv. 12: 487-506.

SAdLER J.P., Bell D. \& Fowles A. 2004: The hydroecological controls and conservation value of beetles on exposed riverine sediments in England and Wales. - Biol. Conserv. 118: 41-56.

SAdLer J.P., Bell D. \& Bates A.J. 2006: The Abundance and Dynamics of Coleoptera Populations on Exposed Riverine Sediments on the River Severn in Wales. CCW Contract Science No. 688. CCW, Bangor, UK, 65 pp.

SÁnchez-Bayo F. \& WyckhuYs K.A.G. 2019: Worldwide decline of the entomofauna: a review of its drivers. - Biol. Conserv. 232: 8-27.

Sinnadura P., Jones T.H. \& Ormerod S.J. 2016: Squeezed out: the consequences of riparian zone modification for specialist invertebrates. - Biodiv. Conserv. 14: 3075-3092.

Skvarla M.J., Larson J.L. \& Dowling A.G.P. 2014: Pitfalls and preservatives: a review. - J. Entomol. Soc. Ont. 145: 15-43.

SLeZaK V., Hora P. \& Tuff I.H. 2010: Effect of pitfall-trapping on the abundance of epigeic macrofauna - preliminary results. Acta Soc. Zool. Bohem. 74: 129-133.

Spence J.R. \& Niemelä J.K. 1994: Sampling ground beetle assemblages with pitfall traps: the madness and the method. Can. Entomol. 126: 881-894.

SYSTAT 2019: Systat Software. 8.0. San Jose, CA.

Taboada A., Kotze D.J., TÁrrega R. \& Salgado J.M. 2006: Traditional forest management: do carabid beetles respond to human-created vegetation structures in an oak mosaic landscape? -For. Ecol. Manag. 237: 436-449.

Thomas C.F.G., Brown N.J. \& Kendall D.A. 2006: Carabid movement and vegetation density: implications for interpreting pitfall trap data from split-field trials. - Agric. Ecosyst. Environ. 113: 51-61.

UlYSHEN M.D. \& HoRn S. 2010: An appeal to protect and restore exposed riverine sediments (ERS) in North America. In Hayes G.D. (ed.): Stream Restoration: Halting Disturbances, Assisted Recovery and Managed Recovery. Nova Science, Hauppauge, pp. 173-176.

Ulyshen M.D., Hanula J.L., Horn S., Kilgo J.C. \& Moorman C.E. 2005a: The response of ground beetles (Coleoptera: Carabidae) to selection cutting in a South Carolina bottomland hardwood forest. - Biodiv. Conserv. 15: 261-274.

Ulyshen M.D., Hanula J.L. \& Horn S. 2005b: Using Malaise traps to sample ground beetles (Coleoptera: Carabidae). Can. Entomol. 137: 251-256.

VERBERK W. 2011: Explaining general patterns in species abundance and distributions. - Nat. Edu. Know. 3(10): 38, 11 pp.

Winder L., Holland J.M., Perry J.N., Woolley C. \& AleXanDER C.J. 2001: The use of barrier-connected pitfall trapping for sampling beetles and spiders. - Entomol. Exp. Appl. 98: 249-258.

Received September 19, 2019; revised and accepted January 28, 2020 Published online February 10, 2020 